\title{
Biomass structure of Pinus sylvestris and Betula pendula forest ecosystems in pollution gradient near copper plant on the Southern Ural
}

\author{
Vladimir A. Usoltsev ${ }^{1,2}$, Walery Zukow ${ }^{3 *}$, Viktor P. Chasovskikh ${ }^{1}$ \\ ${ }^{1}$ Ural State Forest Engineering University Sibirskii trakt str., 37, Yekaterinburg, 620100 Russian Federation \\ ${ }^{2}$ Botanical Garden, Russian Academy of Sciences, Ural Branch, 8 Marta str., 202a, \\ Yekaterinburg, 620144 Russian Federation \\ ${ }^{3}$ Faculty of Earth Sciences and Spatial Management, Nicolaus Copernicus University, Lwowska 1 str., \\ 87-100 Toruń, Poland, \\ *e-mail: zukow@umk.pl
}

Received: 25 September 2019 / Accepted: 29 October 2019

\begin{abstract}
In the gradient of pollution from the Karabash copper smelter in the Southern Urals $\left(55^{\circ} 29^{\prime} \mathrm{N}, 60^{\circ} 13^{\prime} \mathrm{E}\right)$ in predominantly pure Scots pine and white birch stands, 12 and 34 sample plots are established, respectively, on which 42 and 56 model trees are taken, respectively, by stem diameter. The pollution gradient is expressed by the toxicity index suggested with a relative index of the content in the litter of three "technogenic" metals $\mathrm{Cu}, \mathrm{Pb}$ and $\mathrm{Fe}$. Regression analysis of the dependence of biomass and NPP of trees and stands from toxicity index is performed. There is a log-log-linear pattern of reduction of biomass and annual NPP of spruce-fir forest stands with increasing toxicity index in the direction to the source of pollution, but for the biomass of trees in the same gradient no consistent pattern is detected. The dry matter content (DMC) in all biomass components depends on the toxicity index and species at a statistically significant level: due to the increase in the toxicity index, it decreases in wood and bark, and increases in foliage and branches. At the same toxicity index, DMC in the branches and stem wood more in birch, but in the bark and foliage - in pine. In the wood and bark of a stem, this index is also related to the position in a stem: in the wood it decreases, and in the bark it increases in the direction from the bottom up.
\end{abstract}

Key words: Scots pine, white birch, air pollution, copper smelter, model trees, sample plots, toxicity index, regression analysis.

\section{Introduction}

An integral indicator reflecting the natural and anthropogenic impact on forest ecosystems is their biological productivity. Assessment of biological productivity, or carbondepositing capacity of forests is now reaching the global level, and its increase is one of the main factors of climate stabilization, but "our understanding of changes in terrestrial biomass remains rudimentary" (Houghton et al., 2009).
This uncertainty is increasingly exacerbated by an air pollution factor. It is found that even a slight decrease in the biological productivity of forests under the influence of pollution has substantial negative impact on carbondepositing function of forest cover (Savva \& Berlinger, 2010), which reduces the "assimilation" resource forest cover and the opportunity to obtain benefits to the market of environmental services (Kozhukhova, 2001).

It is necessary to study the influence of atmospheric pollution on changes in the structure of biomass and net 
primary production (NPP) of forest ecosystems in gradients of industrial pollution. The lack of such information is one of the most important reasons that make it difficult to build an overall picture of the transformation of biota under the influence of industrial pollution (Zvereva \& Kozlov, 2012).

The vast expanses of the background environment of the Urals, combined with the presence of large long-term sources of air pollution, provide a unique opportunity to engage in experimental work with entire ecosystems at the level of territorial complexes. In the Urals one of the most intensive sources of toxic emissions is the copper production, in particular, the Karabash copper plant - KCP), Chely-

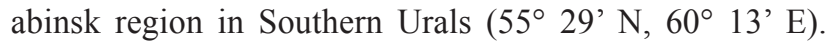
Because of the strong anthropogenic pollution on the territories plant nearest to KCSP, zonal ecosystems are completely destroyed: vegetation and soil humus are missing and an extensive technogenic wasteland is formed (Fig. 1).

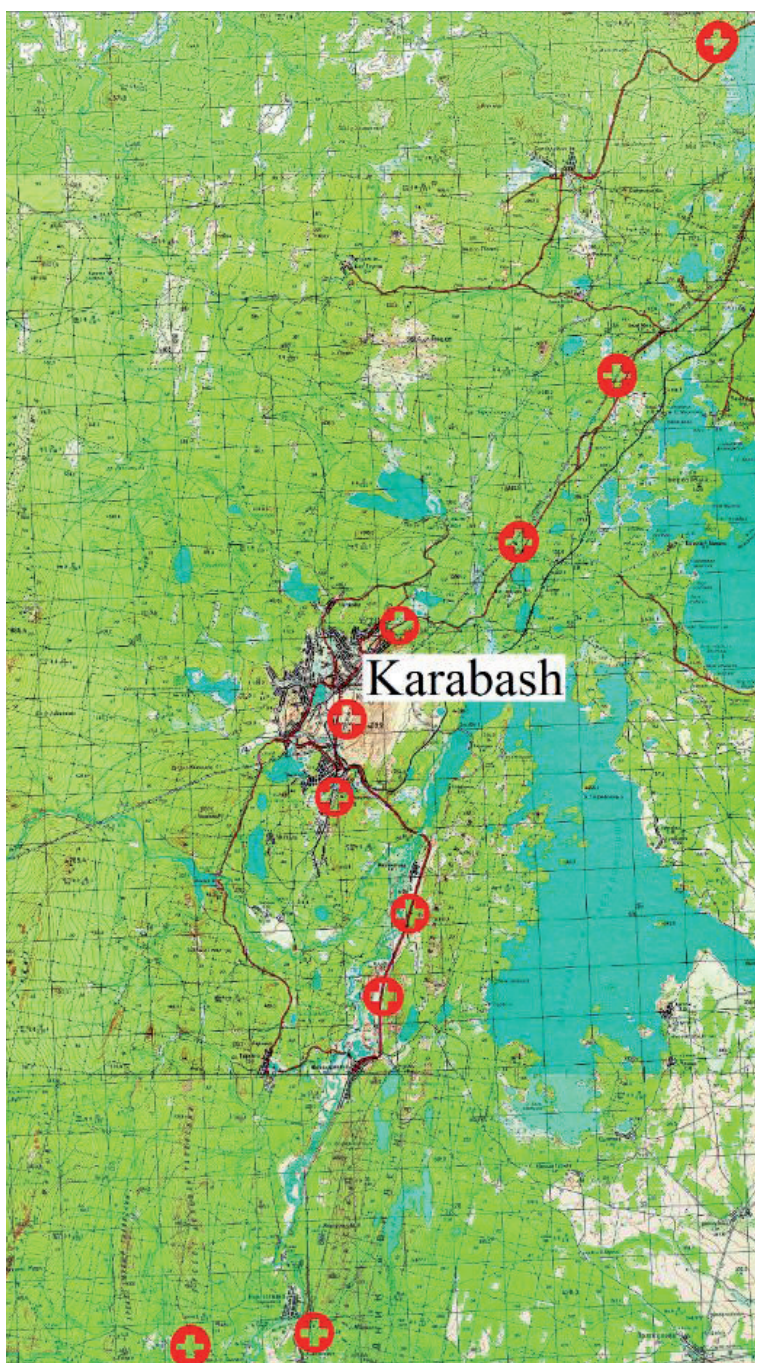

Figure 1. Locations of sample plot establishing in the northeast and south direction from KCP
Many publications describe vegetation reactions to technogenic pollution at the KCP polygon (Chernenkova et al., 1989; Stepanov et al., 1992; Chernenkova, 2002; Kozlov et al., 2009; Koroteeva et al., 2011; Kuyantseva et al., 2011). It was found that radial growth of pine is reduced by 2 times on the gradient of pollution at distances from 1 to $18 \mathrm{~km}$ in southern direction of the $\mathrm{KCP}$, while there is a violation of the growth correlation with climatic factors (Kucherov \& Muldashev, 2003). The radial growth also decreases as the sources of pollution are approached in white birch in the Central Urals (Makhnev et al., 1990), in Latvian Scots pine (Liepa et al., 1986) and in Siberian fir in Central Siberia (Pavlov, 2006).

As a result of studying the influence of atmospheric emissions of KCP on the apical growth, length and state of needles, the number of resin passages on the cross-section of needles of Scots pine, it was found that the apical growth depends on the amount of gross emissions of KCP. The most sensitive to air emission of KCP are the needle length in Scotch pine (Agikov, 2012), and the area of the leaf blade in white birch (Kuyantseva et al., 2011). The integral index of heavy metal content increases most significantly in leaves and to a lesser extent in bark and wood as birch trees approach the KCP (Koroteeva et al., 2015).

It is stated the increase of crown defoliation in Scots pine stands up to $50 \%$ as they approach the Krasnouralsky copper smelter (Vlasenko et al., 2001), the 4-5-fold increase of tree crown transparency as they approach pollution sources in different regions (Sidaravicius, 1987; Yarmishko, 1990; Brassel \& Schwyzer, 1992; Nizametdinov, 2009), but, at the same time, the density of needles on tree shoots is increasing (Augustaitis, 1989; Yarmishko, 1997; Zarubina, 2011). These two opposite trends overlap, and as a result, as we approach the source of pollution, there is no significant decrease in the biomass of trees, as was shown by the example of spruce and fir in the pollution gradient in the Central Urals (Usoltsev et al., 2011, 2012). However, at the stand level, all researchers of biomass structure of different species in pollution gradients came to an unambiguous conclusion about biomass decrease as it approaches the source of pollution (Lukina \& Nikonov, 1991; Stepanov et al., 1992; Yusupov et al., 1997; Chernenkova, 2002; Martynyuk, 2011; Usoltsev et al., 2012).

The purpose of this study is to establish patterns of changes in the structure of biomass and NPP of trees and stands of Scots pine and white birch in connection with an increase in the toxicity index in the pollution gradient at the Karabash copper smelter in the Southern Urals.

\section{Objects and methods}

The Karabash copper plant (KCP) has been operating since 1910. The main emission ingredients are sulfur dioxide 
( $91 \%$ by weight among gaseous pollutants) and dust particles with adsorbed toxic elements $(\mathrm{Cu}, \mathrm{Pb}, \mathrm{Zn}, \mathrm{Cd}, \mathrm{Fe}$, $\mathrm{Ni}$, etc.). The volume of emissions for the entire period of plant operation amounted to more than 15 million tons (Usoltsev et al., 2012).

The studies were carried out in two pollution gradients in predominantly pure birch and pine stands northeast of the KCP, and in birch stands also south of the plant (Fig. 1). 12 and 34 sample plots are established, in Scots pine (Table 1) and white birch (Table 2) stands respectively. The methods of work on the sample plots were described earlier (Usoltsev et al., 2011, 2012).

A total of 42 sample trees for pine and 56 ones for birch were taken. The number of disks sawn from the stems to determine the qualitative indices of wood and bark is following: 126 for pine and 168 for birch; the number of definitions of qualitative indices of the crown at the samples of foliage and branches (crown skeleton): 102 pine and 56 birch. To determine the biomass and NPP of regenera- tions and brushes, 169 and 515 sample trees of pine and birch are taken, respectively. Shares of the regenerations, brushes and grasses in the understory biomass and NPP in different pollution zones are shown in Table 3.

To estimate the stability of ecosystems, to predict their response to pollutants, to find the maximum permissible loads, it is necessary to build "dose - effect" relationships (Stepanov, 1988; Armand et al., 1991; Vorobeychik \& Khantemirova, 1994; Mikhailova \& Vorobeychik, 1995). It was revealed that the content of heavy metals in the humus layer of the soil changes in the pollution gradient at the KCP as it is removed from it, and this relationship has a nonlinear character (Koroteeva et al., 2015). Therefore, as an indicator of the "dose" we have adopted the toxicity index (index2), calculated from the concentration of mobile forms of the three most "manmade" metals $(\mathrm{Cu}, \mathrm{Pb}$ and $\mathrm{Fe})$ deposited in the forest litter, i.e. those metals that have the highest exceedances above the minimum level at the three dirtiest sites and the lowest

Table 1. Tree species composition* and taxation characteristics and harvest data** of stand aboveground biomass on 12 sample plots established in predominantly pure pine stands in the pollution gradient at the $\mathrm{KCP}$

\begin{tabular}{|c|c|c|c|c|c|c|c|c|c|c|c|c|c|c|c|c|c|c|}
\hline $\begin{array}{c}\text { Pollution } \\
\text { zone }\end{array}$ & $\begin{array}{c}D, \\
\mathbf{k m}\end{array}$ & $\begin{array}{c}\text { Species } \\
\text { composition }\end{array}$ & $A$ & $\boldsymbol{H}$ & $D B H$ & $N$ & $G$ & $V$ & Ps & $P b$ & $P f$ & $P a$ & $P u$ & $Z s$ & $Z \boldsymbol{b}$ & $Z f$ & $Z a$ & $Z u$ \\
\hline \multirow{2}{*}{ Impact } & 4.2 & 7Ps3Bp & 80 & 20.6 & 26.9 & 392 & 15.97 & 179 & 84.1 & 11.9 & 3.65 & 99.6 & 0.12 & 1.05 & 0.446 & 1.30 & 2.82 & 0.112 \\
\hline & 5.5 & 9Ps1Bp & 80 & 19.9 & 31.1 & 422 & 27.97 & 323 & 154.2 & 22.2 & 6.97 & 182.2 & 0.33 & 1.94 & 0.774 & 1.66 & 4.4 & 0.312 \\
\hline \multirow{9}{*}{ Buffer } & 5.8 & $10 \mathrm{Ps}$ & 80 & 21.2 & 31.1 & 504 & 34.46 & 485 & 199,0 & 16.9 & 9.21 & 214.9 & 1.08 & 1.84 & 0.64 & 1.41 & 3.96 & 0.418 \\
\hline & 6.6 & $8 \mathrm{Ps} 1 \mathrm{Bp} 1 \mathrm{Pt}$ & 80 & 19.8 & 28.4 & 440 & 26.33 & 368 & 164.3 & 15.4 & 6.63 & 179.7 & 1.08 & 1.57 & 0.602 & 1.61 & 3.83 & 0.418 \\
\hline & 7.3 & 10Ps & 80 & 20.4 & 27.6 & 640 & 35.74 & 468 & 196,0 & 17,0 & 8.31 & 214.8 & 1.08 & 1.86 & 0.675 & 1.54 & 4.15 & 0.418 \\
\hline & 8.3 & 8Ps1Bp1Ls & 80 & 19.5 & 23.8 & 560 & 25.64 & 275 & 123,0 & 12.5 & 5.00 & 140.9 & 1.21 & 1.37 & 0.507 & 1.43 & 3.25 & 0.503 \\
\hline & 8.8 & 7Ps3Bp & 80 & 18.6 & 27.8 & 437 & 24.6 & 322 & 151.5 & 16.2 & 4.46 & 171.2 & 1.21 & 1.36 & 0.618 & 2.10 & 3.91 & 0.503 \\
\hline & 9.5 & 7Ps3Bp & 80 & 18.6 & 28.4 & 434 & 27.23 & 401 & 175.8 & 22.1 & 4.46 & 202.7 & 1.10 & 1.56 & 0.774 & 2.63 & 4.75 & 0.610 \\
\hline & 13.3 & 10Ps & 80 & 20.4 & 27.6 & 549 & 30.64 & 373 & 177.3 & 16.7 & 8.63 & 203.5 & 1.08 & 2.39 & 0.59 & 1.80 & 4.79 & 0.726 \\
\hline & 13.8 & 10Ps & 80 & 20.6 & 27.7 & 591 & 32.48 & 386 & 183.9 & 17.3 & 9.10 & 211.1 & 1.08 & 2.47 & 0.613 & 1.80 & 4.91 & 0.726 \\
\hline & 14.5 & 9Ps1Bp & 70 & 19.5 & 25.3 & 989 & 43.69 & 512 & 234.3 & 21.9 & 10.1 & 268.0 & 1.08 & 3.25 & 0.853 & 2.29 & 6.49 & 0.726 \\
\hline $\begin{array}{l}\text { Back- } \\
\text { ground }\end{array}$ & 32.0 & 8Ps2Bp & 80 & 20.3 & 28.5 & 600 & 35.0 & 492 & 196.7 & 17.6 & 6.70 & 219.8 & 1.25 & 2.98 & 0.85 & 2.21 & 5.97 & 0.573 \\
\hline
\end{tabular}

*Species designations: Ps - Pinus sylvestris L., Bp - Betula pendula Roth., Pt - Populus tremula L., Ls - Larix sibirica L.

** Stand designations: $D$ is distance from pollution source, $\mathrm{km} ; A$ is stand age, yrs; $H$ and $D B H$ are mean height and mean diameter at breast height correspondingly, in $\mathrm{m}$ and $\mathrm{cm} ; N$ is tree number per ha; $G$ is basal area, $\mathrm{m}^{2}$ per ha; $V$ is volume stock, $\mathrm{m}^{3}$ per ha; $P_{i}$ and $Z_{i}$ are biomass and annual NPP, t per ha; $i$ is the index of biomass component: stem with bark $(s)$, branches $(b)$, foliage $(f)$, aboveground $(a)$, and understory $(u)$. 


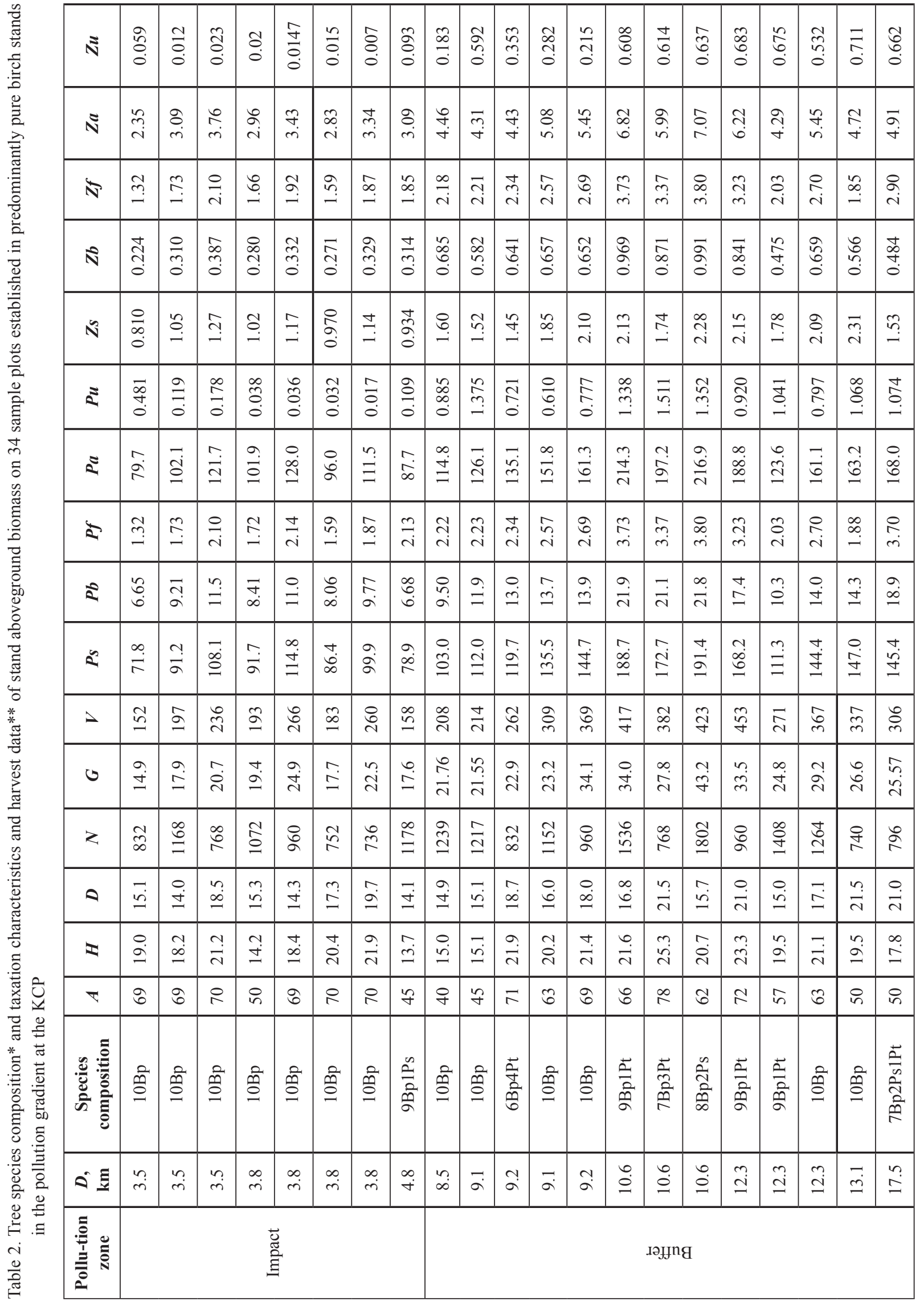




\begin{tabular}{|c|c|c|c|c|c|c|c|c|c|c|c|c|c|}
\hline ลี & $\begin{array}{l}8 \\
\infty \\
0 \\
0\end{array}$ & $\stackrel{\Xi}{\Xi}$ & $\stackrel{+}{\stackrel{+}{0}}$ & 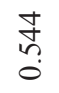 & $\begin{array}{l}\stackrel{2}{2} \\
0 \\
0\end{array}$ & $\hat{\hat{a}}$ & $\begin{array}{l}\infty \\
\infty \\
0 \\
0\end{array}$ & $\begin{array}{l}\dot{H} \\
\tilde{\sigma} \\
\hat{o}\end{array}$ & $\overrightarrow{0}$ & 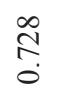 & है. & 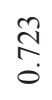 & $\begin{array}{l}\bar{y} \\
\overline{0} \\
\bar{z} \\
\bar{c} \\
\bar{c}\end{array}$ \\
\hline$\Sigma$ & $\underset{\hat{n}}{\hat{\infty}}$ & 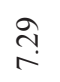 & $\begin{array}{l}n \\
\infty \\
\infty\end{array}$ & $\underset{\infty}{\stackrel{a}{0}}$ & $\vec{\sigma}$ & $\underset{\sim}{\stackrel{\infty}{r}}$ & 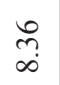 & $\frac{m}{\dot{n}}$ & 年 & $\underset{\infty}{\underset{\infty}{f}}$ & के & $\stackrel{9}{\stackrel{0}{0}}$ & $\frac{20}{00}$ \\
\hline s & 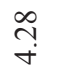 & $\stackrel{\vec{r}}{r}$ & $\stackrel{n}{\tilde{r}}$ & $\stackrel{0}{\rightarrow}$ & $\underset{\text { ָ̦ }}{+}$ & $\stackrel{\mathscr{\vartheta}}{\dot{t}}$ & $\underset{+}{\vec{f}}$ & $\stackrel{R}{i}$ & $\begin{array}{l}\infty \\
\infty \\
i\end{array}$ & 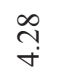 & $\underset{+}{\stackrel{+}{+}}$ & $\hat{n}$ & $\frac{0}{n}$ \\
\hline งิ & $\stackrel{0}{=}$ & $\underset{\dot{\sigma}}{-}$ & $\stackrel{\text { }}{-}$ & $\underset{\stackrel{2}{0}}{\stackrel{2}{0}}$ & 离 & $\begin{array}{l}\tilde{W} \\
0 \\
0\end{array}$ & $\stackrel{m}{\stackrel{m}{0}}$ & $\mid \begin{array}{l}n \\
0 \\
0 \\
0 \\
\end{array}$ & $\hat{n}$ & $\begin{array}{l}t \\
\stackrel{0}{0} \\
0\end{array}$ & $\stackrel{\circ}{\stackrel{2}{0}}$ & 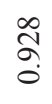 & .50 \\
\hline$\hat{v}$ & $\begin{array}{l}\mathscr{\infty} \\
\stackrel{i}{i}\end{array}$ & $\stackrel{\text { aे }}{\mathrm{i}}$ & $\hat{\widehat{i}}$ & $\vec{ָ}$ & $\underset{\hat{r}}{\hat{r}}$ & $\hat{\widehat{i}}$ & $\stackrel{\ddot{n}}{\ddot{n}}$ & $\hat{\alpha}$ & $\underset{r}{o}$ & $\underset{q}{q}$ & $\stackrel{n}{n}$ & $\begin{array}{l}\stackrel{\partial}{r} \\
\dot{r}\end{array}$ & 营 \\
\hline$\approx$ & $\stackrel{\tilde{\sigma}}{\tilde{\sigma}}$ & $\stackrel{+}{n}$ & 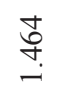 & $\underset{\Xi}{\Xi}$ & 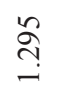 & $\stackrel{\infty}{\stackrel{\infty}{\unlhd}}$ & $\stackrel{2}{\circ}$ & 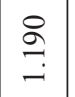 & $\begin{array}{l}\infty \\
\stackrel{\infty}{\dddot{N}} \\
\rightarrow\end{array}$ & 导 & 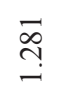 & तָ & 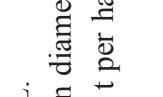 \\
\hline$\approx$ & 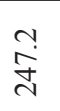 & $\overrightarrow{\vec{a}}$ & $\frac{n}{\dot{D}}$ & $\begin{array}{c}\stackrel{\circ}{\mathrm{i}} \\
\stackrel{\sim}{\vec{\lambda}}\end{array}$ & $\begin{array}{l}\circ \\
\stackrel{\vec{\lambda}}{\mathbf{N}}\end{array}$ & ì & $\begin{array}{l}\text { ڤे } \\
\text { iे }\end{array}$ & $\mid \begin{array}{l}n \\
0 \\
n \\
n\end{array}$ & $\vec{a}$ & $\begin{array}{l}0 \\
\infty \\
\infty \\
\infty\end{array}$ & $\stackrel{+}{\dot{\vec{D}}}$ & $\begin{array}{l}0 \\
\infty \\
\infty \\
\infty \\
\sim\end{array}$ & 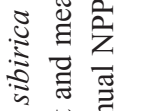 \\
\hline 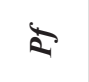 & $\stackrel{\infty}{\sim} \underset{f}{+}$ & $\stackrel{r}{i}$ & $\stackrel{n}{r}$ & $\stackrel{\odot}{\underset{f}{+}}$ & $\underset{\sim}{\stackrel{\sim}{*}}$ & $\stackrel{n}{o}$ & $\underset{f}{\vec{f}}$ & $\stackrel{?}{i}$ & $\begin{array}{l}\infty \\
\infty \\
i\end{array}$ & $\stackrel{\infty}{\underset{\gamma}{\sim}}$ & $\underset{⿱}{\stackrel{t}{*}}$ & $\stackrel{n}{n}$ & 3 \\
\hline 2 & 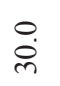 & 㐫 & $\overrightarrow{\mathrm{i}}$ & $\stackrel{\circ}{\stackrel{\infty}{-}}$ & $\stackrel{m}{\infty}$ & $\stackrel{n}{=}$ & $\stackrel{0}{2}$ & $\stackrel{\check{\Xi}}{=}$ & $\vec{g}$ & $\begin{array}{l}n \\
\infty \\
\infty\end{array}$ & in & $\stackrel{m}{\pi}$ & \\
\hline 2 & 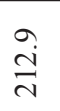 & $\begin{array}{l}n \\
\infty \\
\infty \\
\infty\end{array}$ & $\stackrel{\check{d}}{\stackrel{\Delta}{d}}$ & $\begin{array}{l}\infty \\
\stackrel{i}{े}\end{array}$ & $\begin{array}{l}\stackrel{0}{0} \\
\stackrel{\vec{i}}{0}\end{array}$ & 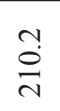 & $\begin{array}{l}\stackrel{+}{\Delta} \\
\stackrel{\Delta}{\Delta}\end{array}$ & $\left|\begin{array}{l}a \\
\dot{n} \\
n \\
-\end{array}\right|$ & $\stackrel{\vec{n}}{\ddot{n}}$ & $\stackrel{a}{\vec{n}}$ & $\begin{array}{l}\text { तె } \\
\text { } \\
\end{array}$ & ڤें & $\Xi$ \\
\hline$\Delta$ & $\hat{n}$ & $\ddot{q}$ & $\stackrel{\infty}{+}$ & $\hat{\widehat{n}}$ & $\underset{\infty}{\stackrel{\infty}{+}}$ & $\dddot{q}$ & $\tilde{n}$ & $\frac{\infty}{m}$ & $\hat{\grave{\lambda}}$ & 号 & $\tilde{n}$ & $\hat{\varepsilon}$ & \\
\hline ن & $\begin{array}{l}\infty \\
\dot{m}\end{array}$ & n? & $\hat{\delta}$ & $\vec{m}$ & $\hat{\dot{m}}$ & $\frac{m}{m}$ & $\begin{array}{l}\infty \\
\dot{m} \\
\dot{m}\end{array}$ & $\stackrel{\circ}{\dot{+}}$ & 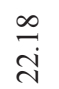 & $\frac{a}{m}$ & $\stackrel{n}{n}$ & ণ্ं & \\
\hline z & $\approx$ & ָి & $\stackrel{\infty}{\infty}$ & $\stackrel{\infty}{=}$ & $\stackrel{N}{\approx}$ & $\approx$ & $\stackrel{\circ}{\circ}$ & $\tilde{\infty}$ & 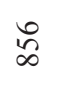 & $\approx$ & ล̊ & 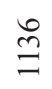 & \\
\hline$\theta$ & $\stackrel{\text { ì }}{ }$ & 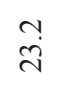 & $\ddot{n}$ & $\stackrel{\circ}{9}$ & $\begin{array}{l}\infty \\
\underset{\sim}{d}\end{array}$ & ठे. & $\stackrel{n}{\sim}$ & $\stackrel{\sim}{\stackrel{N}{N}}$ & $\stackrel{9}{I}$ & $\overrightarrow{\vec{\lambda}}$ & $\stackrel{n}{\vec{\lambda}}$ & $\stackrel{\circ}{\stackrel{i}{v}}$ & $\stackrel{\Xi}{\Xi}$ \\
\hline$\approx$ & $\stackrel{\leftrightarrow}{\stackrel{\sim}{d}}$ & $\begin{array}{l}0 \\
\dot{i}\end{array}$ & 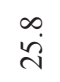 & $\underset{\sim}{\stackrel{\sim}{d}}$ & $\stackrel{m}{\stackrel{m}{\sim}}$ & $\begin{array}{l}n \\
\ddot{n} \\
\end{array}$ & $\vec{i}$ & $\stackrel{\infty}{\sim}$ & $\underline{0}$ & $\begin{array}{l}0 \\
\text { ஸे }\end{array}$ & $\begin{array}{l}\infty \\
\text { ஸे }\end{array}$ & $\begin{array}{l}0 \\
\ddot{i}\end{array}$ & \\
\hline$\nabla$ & 8 & $\approx$ & $\frac{\pi}{2}$ & $\infty$ & $\underset{N}{ }$ & $\nabla$ & $\mathbb{R}$ & $\infty$ & q & $\mathbb{N}$ & $\mathbb{N}$ & $\pi$ & \\
\hline 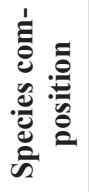 & о्ञ & ڤ్ & 옹 & ڤ્वิ & 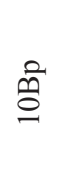 & $\begin{array}{l}n \\
\stackrel{n}{2} \\
\text { ڤn }\end{array}$ & 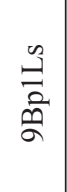 & 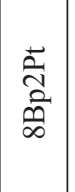 & 용 & 各 & 今응 & 今ิ & 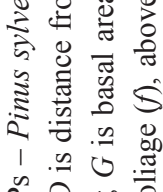 \\
\hline Q & $\begin{array}{l}n \\
\infty\end{array}$ & $\begin{array}{l}n \\
\infty \\
\infty\end{array}$ & $\begin{array}{l}n \\
\infty \\
-\infty\end{array}$ & ì & $\begin{array}{l}\infty \\
\ddot{i}\end{array}$ & $\stackrel{\vec{\infty}}{\stackrel{N}{N}}$ & $\begin{array}{l}\overrightarrow{0} \\
\dot{i} \\
\dot{i}\end{array}$ & 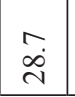 & $\stackrel{\circ}{\stackrel{m}{m}}$ & $\stackrel{\vec{m}}{m}$ & $\stackrel{i}{m}$ & $\stackrel{\vec{m}}{m}$ & 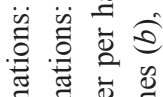 \\
\hline 离 & & 离 & & & & & 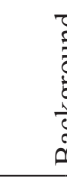 & & & & & & 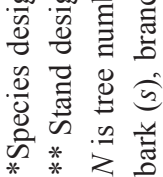 \\
\hline
\end{tabular}


Table 3. Shares of the regenerations, brushes and grasses in the understory biomass and NPP in different pollution zones

\begin{tabular}{|c|c|c|c|c|c|c|c|c|}
\hline \multirow{2}{*}{ Pollution zone } & \multicolumn{4}{|c|}{ Biomass, \% } & \multicolumn{4}{|c|}{ NPP, \% } \\
\hline & Regenera-tion & Brush & Grass & Total & Regeneration & Brush & Grass & Total \\
\hline \multicolumn{9}{|c|}{ Pine stands } \\
\hline Impact & 4 & 2 & 94 & 100 & 0.5 & 0.2 & 99.3 & 100 \\
\hline Buffer & 22 & 34 & 44 & 100 & 4 & 6 & 90 & 100 \\
\hline Background & 16 & 43 & 41 & 100 & 3 & 7 & 90 & 100 \\
\hline \multicolumn{9}{|c|}{ Birch stands } \\
\hline Impact & 32 & 48 & 20 & 100 & 15 & 22 & 63 & 100 \\
\hline Buffer & 20 & 34 & 46 & 100 & 4 & 6 & 90 & 100 \\
\hline Background & 19 & 24 & 57 & 100 & 3 & 3 & 94 & 100 \\
\hline
\end{tabular}

exceedances at the three sites furthest from the emission source. In contrast to sulfur, they are stronger adsorbed by depositing environments, and they are easier to measure on polygons of a large area (Mikhailova \& Vorobeichik, 1995).

In this case, index 2 is calculated for concentrations of mobile forms of $\mathrm{Cu}, \mathrm{Pb}$ and $\mathrm{Fe}$ in forest litter according to the following formula

$$
\text { index2 }=\frac{1}{k} * \Sigma \frac{X_{i j}}{X_{i m i n}}
$$

where, $k$ is a number of elements (in our case - three); $X i j$ is concentration of $i$-th element on $j$-th site; $X_{i \text { min }}$ is minimum concentration of $i$-th element on all sites.

\section{Results and discussion}

To assess the impact of pollution on the structure of tree biomass, the allometric equations are calculated, having the form

$$
p_{i}=\exp \left[\mathrm{a}_{0}+\mathrm{a}_{1} \ln (\mathrm{DBH})+\mathrm{a}_{2}(X)+\mathrm{a}_{3} \ln (I)\right]
$$

where $p_{i}$ is biomass of $i$-th component, $\mathrm{kg}$; DBH is stem diameter at breast height, $\mathrm{cm}$; $I$ is toxicity index (index2); $X$ - binary variable, equal 1 for pine and 0 for birch. The calculation of (2) for aboveground biomass, stems, foliage and branches, showed the following coefficients of determination, correspondingly: $0.981,0.972,0.861$ and 0.951 . The significance level according to the Student's criterion for the constant $\mathrm{a}_{2}$ was 10.6, 9.9, 12.1 and 18.1 respec- tively. This means that the difference of allometric dependences of biomass components upon DBH in pine and birch is highly reliable (at the level of probability $\mathrm{P}_{999}$ ).

But for the constant $\mathrm{a}_{3}$ the significance level was 1.1, $0.9,1.1$ and 0.4 respectively, which is significantly less than the critical value $t_{05}=2$. This means that the biomass structure of equal-sized trees of both species remains unchanged throughout the pollution gradient. As it was mentioned above, this phenomenon may be explained with joining two contrary trends, i.e. firstly, increasing foliage density on twigs and, secondly, increasing crown transparency when approaching pollution source. Thus, these two contrary trends overlap and the total trend is absent.

This also means that ignoring of previously obtained experimental data of tree biomass and seeking new experimental data to calculate "modern" allometric equations, supposedly more appropriate to the changed environmental conditions (Xing et al., 2005), is completely unfounded.

Similar equations are calculated for the annual growth of tree biomass. The obtained equations for each sample plot are further used to calculate biomass and NPP per 1 ha, which are then analyzed in relation to the toxicity index.

A standard regression analysis procedure was used to approximate "dose - effect" relationships. The dependencies were analyzed

$$
\begin{aligned}
& P_{i}=\exp \left[\mathrm{a}_{0}+\mathrm{a}_{1} \ln I+\mathrm{a}_{2}(X \times \ln I)\right], \\
& Z_{i}=\exp \left[\mathrm{a}_{0}+\mathrm{a}_{1} \ln I+\mathrm{a}_{2}(X \times \ln I)\right] .
\end{aligned}
$$

Designations in (3) and (4) see in Table 1. All regression coefficients of the independent variables of the calculated equations are significant at the probability level 
of 0.95 and above. When calculating equations (3) and (4), the taxation characteristics of pine and birch stands were consistently included as additional independent variables. However, in most cases their influence on biomass and NPP of forest stands in the pollution gradient was not statistically reliable. The characteristics of the final equations is given in Table 4 and their graphical interpretation in Figure 2.

If no significant impact on the aboveground biomass and its annual NPP of pine and birch in the gradient of pollution from KCP was revealed at a tree level, at a stand level such an impact was significant. This means that the change in biological productivity of stands in the pollution gradient is influenced not by the structure of biomass and NPP of their constituent trees, but by the taxation structure of stands.

A previously published paper (Usoltsev et al., 2012) the dependence of biomass and NPP of trees and stands was investigated in the same pollution gradient on the $\mathrm{KCP}$, but the pollution index was the distance from the source of pollution. The first output was like this: if an influence of pollution from KCP on aboveground biomass and annual NPP of pine and birch trees in the gradient was no significant, their influence at a forest stand level is obvious.

However, there are differences concerning the traits of the studied dependencies. Judging by the structure of equations (3) and (4), shown in Table 5, and their graphical interpretation (Fig. 2), the obtained dependences of the stands production indices on the toxicity index are described by a simple allometric function, whereas their relation to the distance from the pollution source $(D, \mathrm{~km})$ was described by the equation

$$
P_{i} \text { and } Z_{i}=\mathrm{a}_{0}+\mathrm{a}_{1}(1 / D)^{2},
$$

according to which, after the sharp increase in $P_{i}$ and $Z_{i}$ in the range of distances from 4 to $10 \mathrm{~km}$, as they move away from the KCP, they gradually stabilize with the exit to the plateau.

Since in determining the biological productivity of stands in the sample plots, the main share of labor is spent on determining the dry matter content (DMC) in biomass components, we estimated dependences of DMC in biomass components upon determining factors that could be useful in studies of this nature at similar facilities. The equations for DMC are calculated:

- in stem components

$$
S w \text { and } S b=\mathrm{a}_{0}+\mathrm{a}_{1} I+\mathrm{a}_{2} X+\mathrm{a}_{3} h
$$

- and in foliage and branches

$$
S f \text { and } S b r=\mathrm{a}_{0}+\mathrm{a}_{1} I+\mathrm{a}_{2} X,
$$

where $S w, S b, S f$ and $S b r$ are dry matter content in stem wood and bark, in foliage and branches, respectively, $\% ; h-$ position of sawn disks along the stem, in shares of the stem height, i.e. $0.2,0.5$ and $0.8 H$ (numbering from bottom to top), where $H$ is the stem height, $\mathrm{m} ; I-$ index toxicity (Index 2); $X$ is a binary variable equal to 1 for pine and 0 for birch. All regression coefficients of the independent variables of the calculated equations (6) and (7) are significant at the probability level of 0.95 and above. The characteristic of equations (6) and (7) is given in Table 6.

When judging by the characteristic of equations (6) and (7), the dry matter content in the stem wood decreases and in the bark increases from the bottom up; due to the increase in the toxicity index, DMC in the wood and bark decreases, and in the foliage and branches increases. At the same toxicity index, DMC in the stem wood and branches is more in birch, and in bark and foliage is more in pine.

For preliminary (approximate) calculations or in cases where it is not possible to determine the DMC in the biomass components by the thermal-weight method when

Table 4. Characteristic of equations (3) and (4) for pine and birch stands in the pollution gradient near the KCP

\begin{tabular}{|c|c|c|c|c|c|c|c|c|c|c|}
\hline $\begin{array}{c}\text { Equation } \\
\text { characteristic }\end{array}$ & $\boldsymbol{P a}$ & $\boldsymbol{P s}$ & $\boldsymbol{P f}$ & $\boldsymbol{P b}$ & $\boldsymbol{P u}$ & $\boldsymbol{Z a}$ & $\boldsymbol{Z s}$ & $\boldsymbol{Z f}$ & $\boldsymbol{Z b}$ & $\boldsymbol{Z u}$ \\
\hline $\mathrm{a}_{0}$ & 5.4703 & 5.3530 & 1.5307 & 3.0375 & 0.8666 & 2.0606 & 1.1305 & 1.3444 & -0.1412 & 0.4393 \\
\hline $\mathrm{a}_{1}$ & -0.1755 & -0.1744 & -0.2072 & -0.1701 & -0.6590 & -0.1888 & -0.2281 & -0.1593 & -0.1882 & -0.8222 \\
\hline $\mathrm{a}_{2}$ & 0.1026 & 0.1000 & 0.2932 & 0.1125 & 0.3514 & 0.0165 & 0.0733 & -0.0575 & 0.1058 & 0.4650 \\
\hline$a d j \mathrm{R}^{2}$ & 0.594 & 0.587 & 0.697 & 0.465 & 0.671 & 0.672 & 0.708 & 0.621 & 0.483 & 0.804 \\
\hline $\mathrm{SE}$ & 1.24 & 1.24 & 1.33 & 1.31 & 1.98 & 1.24 & 1.25 & 1.28 & 1.33 & 1.83 \\
\hline
\end{tabular}

Designations of symbols: $P_{i}$ and $Z_{i}$ are biomass and annual NPP, t per ha; $i$ is the index of biomass component: aboveground ( $a$ ), stem with bark $(s)$, foliage $(f)$, branches $(b)$, and understory $(u)$. 

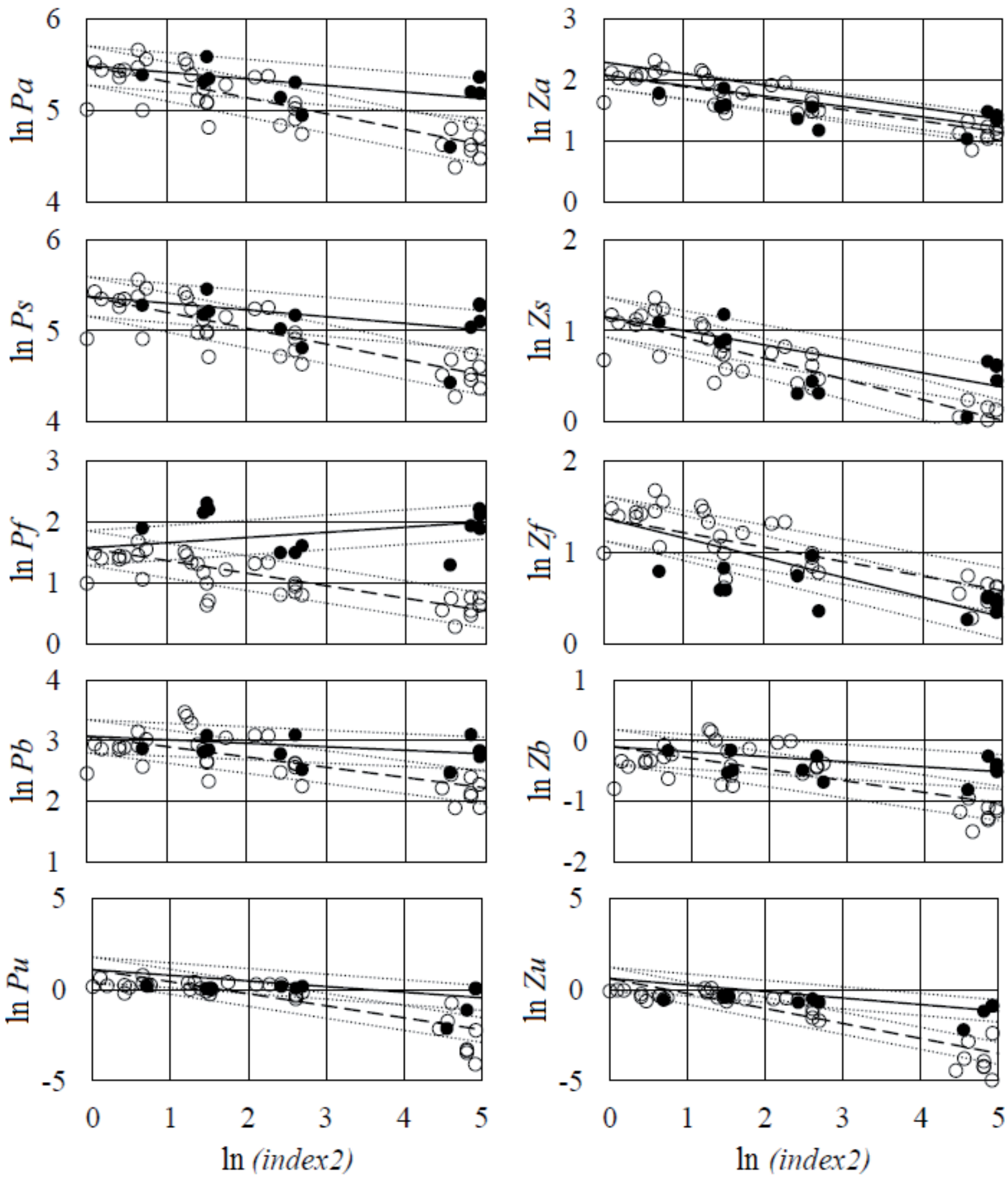

\section{Scots pine}

- - - White birch

Figure 2. Linear log-log change trends of biomass (left) and annual NPP (right) of pine and birch stands in the pollution gradient at KCP. The dotted lines show the range of the standard error of the equations 
Table 6. The characteristic of equations (6) and (7)

\begin{tabular}{|c|c|c|c|c|}
\hline Equation characteristics & $\boldsymbol{S w}$ & $\boldsymbol{S b}$ & $\boldsymbol{S f}$ & \multicolumn{1}{c|}{$\boldsymbol{S b r}$} \\
\hline $\mathrm{a}_{0}$ & 67.13 & 32.58 & 37.86 & 52.69 \\
\hline $\mathrm{a}_{1}$ & -0.024 & -0.022 & 0.011 & -6.155 \\
\hline $\mathrm{a}_{2}$ & -4.39 & 19.35 & 9.26 & - \\
\hline $\mathrm{a}_{3}$ & -18.31 & 6.93 & - & 0.638 \\
\hline$a d j \mathrm{R}^{2}$ & 0.636 & 0.797 & 0.835 & 2.22 \\
\hline $\mathrm{SE}$ & 3.86 & 4.88 & 2.00 & 2.2 \\
\hline
\end{tabular}

Table 7. Average DMC ( \% ) in pine and birch biomass components in the pollution gradient at KCP

\begin{tabular}{|c|c|c|}
\hline Biomass component & Pine & Birch \\
\hline Stem wood & $52.5 \pm 0.60$ & $35.4 \pm 0.44$ \\
\hline Stem bark & $54.1 \pm 0.70$ & $53.1 \pm 0.21$ \\
\hline Branches with their bark & $47.0 \pm 0.23$ & $38.4 \pm 0.20$ \\
\hline Foliage & $47.6 \pm 0.29$ & \\
\hline
\end{tabular}

evaluating it on sample plots in the stands of pine and birch, its average values can be used (Table 7).

\section{Conclusion}

Thus, it is not revealed any statistically significant patterns of change in biomass and annual NPP of trees in the gradient of the index of toxicity, but at the stand level, a linear log-log pattern of declining biomass and annual NPP of forest stands with increasing index of toxicity in the direction to the source of pollution have been established, and most of the components reduce in birch more pronounced than in pine. The exception is the ratio of these trends in pine and birch related to biomass and NPP foliage.

Neither the age of a tree nor its size contribute significantly to the explanation of the variability of DMC in biomass components. But DMC of all the components of biomass depends upon the value of the toxicity index and species on a statistically significant level: due to the increase in the toxicity index, DMC in wood and bark decreases, and in foliage and branches increases. At the same toxicity index DMC in the stem wood and branches above birch, and in the bark and foliage above pine. In the stem wood and bark, this indicator is also related to the position in a stem: in the wood it decreases, and in the bark it increases in the direction from the bottom up.
The use of the toxicity index in the pollution gradient enables a comparative analysis of pollution situations at different sites and some physiologically determined interpretations of the revealed trends.

\section{Acknowledgement}

The authors thank their colleagues E.L. Vorobeichik, I.E. Bergman, M.R. Trubina, S.Y. Kaygorodova, P.G. Pishchulin, A.V. Sapelkin and I. Biktimirov involved in obtaining raw materials and I.S. Tsepordey preparing the manuscript for publication.

\section{References}

Agikov I.N., 2012, The influence of non-ferrous smelt atmospheric emissions on Scots pine (Pinus sylvestris L.) forests (South Urals). Vestnik Udmurtskogo Universiteta 2: 24-30 [in Russian].

Armand A.D., Kaydakova V.V., Kushnareva G.V. \& Dobrodeev V.G., 1991, Determination of the limits of geosystems' stability on the example of the vicinity of the Monchegorsk metallurgical works. Izv. Akad. Nauk SSSR, Ser. Geografich. 1: 93-104 [in Russian].

Augustaitis A.A., 1989, Features of formation of aboveground phytomass of pine young forests in conditions 
of pollution of the environment, [in:] Problems of ecological monitoring and modeling of ecosystems. Vol. 12. Gidrometeoizdat, Leningrad: 32-51 [in Russian].

Brassel P. \& Schwyzer A., 1992, Ergebnisse der Waldschadeninventur 1992, [in:] Sanasilva - Waldschadenbericht 1992. WSL, Bern und Birmensdorf: 7-18.

Chernenkova T.V., 2002, Reaction of forest vegetation to industrial pollution. "Nauka", Moscow, 190 pp. [in Russian].

Chernenkova T.V., Stepanov A.M. \& Gordeeva M..M., 1989 , Changes in the organization of forest phytocenoses in technogenesis. Zhurnal Obshchei Biologii 3: 388-394 [in Russian].

Houghton R.A., Hall F. \& Goetz S.J., 2009, Importance of biomass in the global carbon cycle. Journal of Geophysical Research 114: 1-13 (G00E03, doi:10.1029/2009JG000935).

Koroteeva E.V., Veselkin D.V., Kuyantseva N.B., Mumber A.G. \& Chashchina O.E., 2015, Accumulation of heavy metals in the different Betula pendula Roth organs near the Karabash Copper Smelter. Agrokhimiya (Agrochemie) 3: 88-96 [in Russian].

Koroteeva E.V., Veysberg E.I. \& Kuyantseva N.B., 2011, Assessment of forest cenoflora in the impact zone of the Karabash Copper Smelter (Southern Urals). Izv. Samar. Sci. Center of RAS 13(1): 1005-1011 [in Russian].

Kozhukhova L.I., 2001, Assimilative resource of Russia and its place among the priorities of national forest policy, [in:] National forest policy of Russia / Proc. of the intern. scient.-practical conf. MGUL, Moscow: 154-156 [in Russian].

Kozlov M.V., Zvereva E.L. \& Zverev V.E., 2009, Impacts of point polluters on terrestrial biota: Comparative analysis of 18 contaminated areas. Springer, Dordrecht, $466 \mathrm{pp}$

Kucherov S.E. \& Muldashev A.A., 2003, Radial increment of Scotch pine in the vicinity of the Karabash Copper Smelter. Lesovedenie 2: 43-49 [in Russian].

Kuyantseva N.B., Mumber A.G., Potapkin A.B. \& Gavrilkina S.V., 2011, Reaction of birch stands to acid emissions generated by the Karabash Copper Smelter (Southern Urals). Bulletin of the Orenburg State University 12(131): 98-100 [in Russian].

Liepa I.Ya., Nicodemus O.E., Raman K.K. \& Skudra A.Ya., 1986, Time course of pine forests reaction in conditions of changeable air pollution, [in:] Temporal aspects of modeling and forecasting in ecology. Collection of scientific papers. Latvian State University, Riga: 114-127 [in Russian].

Lukina N.V. \& Nikonov V.V., 1991, Changes in the primary productivity of spruce stands under the influence of man-made pollution in the Kola North. Lesovedenie 4: 37-45 [in Russian].
Makhnev A.K., Trubina M.R. \& Paramonov S.A., 1990, Forest vegetation in the vicinity of non-ferrous metallurgy, [in:] Natural vegetation of industrial and urbanized territories of the Urals. Ural Branch of Academy of Sci. USSR, Sverdlovsk: 3-41 [in Russian].

Martinyuk A.A., 2011, Peculiarities of formation of surface phytomass in young pine stands affected by industrial pollution. Lisoviy Zhurnal 2: 13-18 [in Russian].

Mikhailova I.N. \& Vorobeichik E.L., 1995, Epiphytic lichenosynusia under conditions of chemical pollution: dose-effect dependencies. Russian Journal of Ecology 26(6): 425-431.

Nizametdinov N.F., 2009, Assessment of the state of pine stands in the conditions of agro-industrial pollution of the atmosphere by digital photographs of tree crowns and satellite photographs. Abstract PhD. USFEU, Yekaterinburg, 19 pp. [in Russian].

Pavlov I.N., 2006, Woody plants in conditions of technogenic pollution. Buryatia Publishing House, Ulan-Ude, 360 pp. [in Russian].

Savva Y. \& Berlinger F., 2010, Sulphur deposition causes a large-scale growth decline in boreal forests in Eurasia. Global Biogeochemical Cycles 24 (GB3002, doi:10.1029/2009GB003749).

Sidaravicius I.M., 1987, Analysis of phytomass and morphological structure of crowns of a pine forest under atmospheric pollution, [in:] Research and simulation of growth of forests growing in the polluted natural environment. Collect. of scientific. papers. Lituanian Agrarian Academy, Kaunas: 45-55 [in Russian].

Stepanov A. M., 1988, Methodology of. bioindication and background monitoring of terrestrial ecosystems, [in:] Ecotoxicology and Environmental Protection. Moscow: 28-108 [in Russian].

Stepanov A.M., Kabirov R.R., Chernenkova T.V., Sadykov O.F., Khanislamov G.M., Nekrasova L.S., Butusov O.B. \& Balcewicz L.A., 1992, Integrated environmental assessment of anthropogenic impact on ecosystems of southern taiga / A. M. Stepanov (ed.). Promekologia, Moscow, 246 pp. [in Russian].

Usoltsev V.A., Vorobeichik E.L. \& Bergman I.E., 2012, Biological productivity of Ural forests under conditions of air pollutions: studying a system of regularities. Ural State Forest Engineering University, Yekaterinburg, 366 pp. [in Russian]. (http://elar.usfeu.ru/ handle/123456789/458).

Usoltsev V.A., Vorobeichik E.L., Bornikov A.V. \& Zhanabayeva A.S., 2011, Biological productivity of forests near the Ural copper smelters // Boreal Forests in a Changing World: Challenges and Needs for Actions. Proceedings of 15th IBFRA International Science Conference, August 15-21 2011. V.N. Sukachev Institute of Forest SB RAS, Krasnoyarsk: 193-197. 